\title{
Integrated Design and Optimization Issues for Zero Energy Solar Homes
}

\author{
R. Charron ${ }^{1}$, A. Athienitis, M. Pasini \\ Building, Civil and Env. Engineering Dept., Concordia University, Montreal, QC \\ 1.remi.charron@nrcan.gc.ca
}

\begin{abstract}
Homes that utilise solar thermal and solar photovoltaic $(P V)$ technologies to generate as much energy as their yearly load are referred to as net Zero Energy Solar Homes (ZESH). Various design guidelines exist that help designers determine form and orientation of buildings along with the best combination of thermal mass and windows. Numerous components are essential to achieve the net-zero energy target, including solar thermal collectors, $P V$, and efficient HVAC systems. The Canadian entry in the Solar Decathlon competition demonstrates that designing a house with optimization of solar energy in mind can achieve exceptional results. In the future, design optimization tools could assist designers in determining the most cost effective ZESH design options.
\end{abstract}

\subsection{Introduction}

Homes that utilise solar thermal and solar photovoltaic (PV) technologies to generate as much energy as their yearly load are referred to as net-Zero Energy Solar Homes (ZESH). Bill and Debbie Lord's house in Maine, seen on Figure 1, offers a good example of the possibilities of ZESH [1]. As of May 2005, they had over 893,000 visitors on their website, illustrating the growing interest in the area. ZESH are designed to be highly energy efficient and to utilise passive solar building approaches to minimise their loads; the concept is not new. In fact, the first grid-connected ZESH, The Carlisle House, also designed by Steven Strong, was built in 1980 with $7.5 \mathrm{~kW}$ of PV and $14 \mathrm{~m}^{2}$ of solar thermal collectors. Since then, there have been many one-of-a-kind demonstration projects around the world, with the majority of international initiatives that have promoted the development of low and net-zero energy homes coming in recent years [2,3]. The NRCan CANMET Energy Technology Centre (CETC) in Varennes recently started a multi-year project, $R \& D$ on the Optimization of Low Energy Homes in Canada, to study past projects, existing and emerging technologies, and simulation and optimization software in order to learn what is needed to successfully implement low and net-zero energy homes under Canadian climatic conditions [4]. This paper presents existing design guidelines, and relevant technologies followed by a case study of the Canadian entry in the Solar Decathlon competition put on by the US Department of Energy in Washington DC in October 2005. Following, will be a discussion of a design optimization tool that is being developed based on genetic algorithms (GA) that will assist designers in creating more cost effective ZESH.

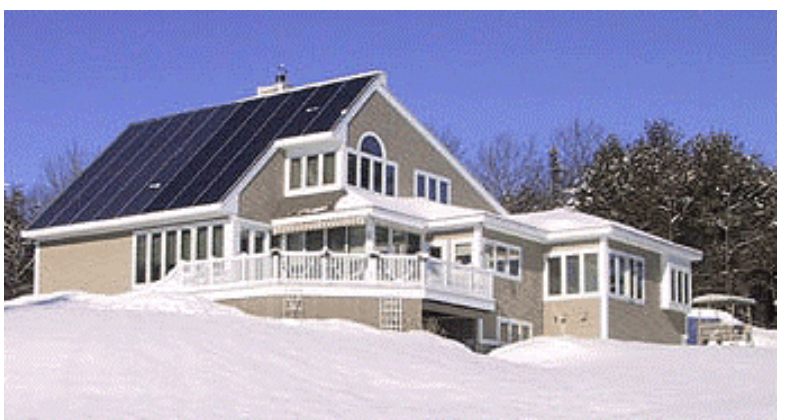

Figure 1: The Lord Residence [1]

\subsection{Design guidelines}

A major requirement in solar-optimized building design is to first select an optimal form and orientation of the building for a given site. Without following this step first, subsequent simulation of design options is often done to justify decisions made on a subjective basis. The design team is faced with numerous parameters with various degrees of freedom. Variables that significantly influence solar energy utilization include window area, window thermal and optical characteristics, PV collector area and orientation, solar thermal collector area and orientation, thermal storage, HVAC system variables, and control strategies. There exist various guidelines and rules of thumb that can be used to help guide the designer in specifying the appropriate parameters. This section will identify some of the existing guidelines. 
Landscaping

Landscaping is an important element of passive solar design. Trees can help the performance by providing a barrier from the cold incoming wind, and provide shading in the summer. On the other hand, trees can be detrimental in the performance of passive housing design, as they can block the incoming solar radiation required to heat the house. According to the Sustainable Building Industry Council, evergreens should be located at least 3 times their projected (mature) height away from the south wall of the house [5]. When PV is used, shading on the modules should be avoided as even a little shade on one part of the modules can significantly impact the performance of the whole system as cells are typically connected in series.

\section{Floor plan and orientation}

As a general rule, a rectangular floor plan works best for passive solar design with the long axis (east-west axis) of the house oriented within 10 degrees of true south [5]. If the house needs to be off-south orientation, east is better than west as it will help heat the house in the early morning, and avoid direct sunlight in the afternoon. The ideal length to width ratio is 1.3 to 1.5 [5]. A two-story compact house is better than a single story house since its exterior building envelope is smaller per unit size of floor space. The layout of the interior space should be done in such a way that daily activities correspond to the sun's predictable path across the sky $[5,6]$. In addition, the internal layout should promote natural ventilation with the use of large open spaces, openings for air to flow between floors and between north and south zones. When partition walls are needed, it is better to orient them in the north-south direction to allow for better north-south ventilation. Finally, lightweight surfaces should be painted in lighter colours to allow for more light to be directed to the massive surfaces [6].

Thermal mass, windows and other envelope features Thermal mass plays an important role in the design of passive solar houses. The mass allows for more heat to be captured, and the heat distribution is modulated allowing for less temperature swings in the house. The optimal amount of thermal mass that is required will depend on the amount of glazing that is used. A typical wood framed house already has a certain amount of thermal mass associated with the construction materials, particularly gypsum board and ceramic tiles. Additional thermal mass is only required when the south-facing window area is larger than 7 to
$8 \%$ of the total heated floor space $[5,6]$ and the amount depends on the allowable room temperature swing.

The location of the mass also plays an important role in determining how much mass is required; mass that is heated indirectly by warm air from the living space is reported to require roughly 4 times more area as the same mass in direct sun to provide the same thermal effect [5]. One drawback of thermal mass is that it is generally colder to the touch, which may prompt people to cover it with carpeting, or other flooring. However, carpet can reduce effectiveness of thermal mass by up to $70 \%$, and vinyl floors by up to $50 \%$ [6]. The effectiveness of most forms of thermal mass increases proportionately up to $100 \mathrm{~mm}[5,6]$. Chiras (2002) offers the following three glass-to-mass ratios to help determine how much $10-15 \mathrm{~cm}$ thick mass to use:

1. Each square metre of south facing window beyond $7 \%$ floor space requires an additional $5.5 \mathrm{~m}^{2}$ of uncovered and sunlit floor mass;

2. For mass not in contact but in same room, an additional $40 \mathrm{~m}^{2}$ of mass is required per additional square metre of south facing glazing above $7 \%$; or

3. $8.3 \mathrm{~m}^{2}$ of wall mass for each square metre of south facing glazing above $7 \%$.

Therefore, the optimal amount of glazing depends on the total heated floor area, total thermal mass, and other design parameters. In general, for direct gain passive solar heating, the solar south-facing glazing should range between $7-12 \%$ of total floor space. In passive solar homes with two or more solar features (thermal mass, sunspace, etc), the total allotment of south-facing glass can be increased substantially, but should generally not exceed $20 \%$ of the heated floor space. Utilization of automatically controlled motorized reflective blinds and possibly active heat storage may enable effective use of south-facing window areas close to $20 \%$ of floor area [7]. In directgain passive solar houses in most climates, north- and east-facing glass should be minimized, each accounting to no more than $4 \%$ of total floor space. West-facing glass should not exceed $2 \%$ of total floor space [5]. As a general rule, one larger window is preferred to several small windows. To allow for good natural ventilation in the cooling season, $6-8 \%$ operable windows to the conditioned floor area are needed. It is best to locate the operable windows on opposite walls in the direction of prevailing summer winds [6].

Thermal mass is not the only consideration in passive housing design. Increased insulation is required when houses are built in areas that experience either cold climates, or hot climates. In these areas, it is 
recommended that the wall insulation be at a minimum of RSI 5 to 7, and ceilings at minimum RSI 8.7 to 10.5 [5]. Chiras (2002) also provides a number of guidelines pertaining to windows. Low-emissivity windows are essential for optimal energy performance; however, requirements for north, south, east, and west windows may differ. In general, U-values of smaller than $1.7 \mathrm{~W} / \mathrm{m}^{2} \cdot \mathrm{K}$ and with certified air leakage rates of less than $1.5 \times 10^{-4} \mathrm{l} / \mathrm{s} / \mathrm{cm}^{2}$ are required for passively conditioned homes. The optimal solar heat gain coefficient (SHGC) is dependent on climate; for hot climates it is recommended to be under 0.4, for intermediate climates between 0.4-0.55, and for cold climates 0.55 or greater [5]; if clerestory windows are used, it is suggested that they should be placed in front of intended mass walls, usually at a distance of approximately 1 to 1.5 times the height of the wall to ensure maximum contact. The proper design and placement of overhangs is an important aspect of passive solar buildings. When properly designed, overhangs will block out direct solar radiation during the summer, and will permit direct solar radiation in the winter. As a general rule, overhangs should be used such that they do not shade windows on Dec. 21, and shade 50 to $100 \%$ of the window on June 21 [6].

There are various other strategies that can be used in solar buildings to capture the sun's energy. CMHC (1998) states that Trombe (collector storage) walls are generally not effective in colder climates (Canada), as they are not insulated, which results in significant heat loss at night. The same reference [6] discourages the use of isolated storage systems, such as rock beds, as the energy required to circulate the heat, and the heat losses generated from the systems may make them not as efficient as desirable.

\section{$\underline{\text { HVAC systems }}$}

Fewer guidelines are available regarding HVAC systems as these generally depend on the type of heating, ventilation, and cooling system that is in place. The US Department of Energy (US DOE) reports that it is common for heating systems to be 2-3 times larger than necessary; as a rule of thumb, it should be no more than 25\% larger than calculated heating loads [5]. In order to ensure adequate comfort levels and to reduce heating loads, the temperature in the heating season should only go above $25^{\circ} \mathrm{C}$ for $4 \%$ of the heating season [6]. For ventilation, circulating fans should only be turned on when the hot space is $3-4^{\circ} \mathrm{C}$ hotter than cold space, and summer ventilation should allow roughly $10 \mathrm{ach}$, with most exhaust coming from hot spaces [6]. A heat recovery ventilator should be used with effectiveness ranging from 80 to $85 \%$.
When installing radiant-floor heating systems, it is important to insulate underneath the floor and around the perimeter of the foundation; $5-10 \mathrm{~cm}$ of rigid foam insulation is reported to work well [5]. In the IEA task 26 on solar combisystems, which are described in the next section, TRNSYS was used to optimize the system. The results indicated that for small systems, 2 to $5 \mathrm{~kW}$ of heat load, that the optimum storage volume is from 50 to $2001 / \mathrm{kW}$, and that the optimum tilt was 30 to 75 degrees, and that orientation was best between 30 degrees east and 45 degrees west [8].

\subsection{Relevant technologies}

One of the greatest challenges in designing a ZESH for Canada will be to meet the heating loads demanded by its harsh winters. The design of the house will include passive heating techniques in conjunction with an efficient airtight envelope construction with highly insulated walls to reduce the heating load. However, these strategies alone will generally not be sufficient to meet the heating needs during the coldest days in winter.

\section{Solar combisystems}

An interesting option for heating is to use solar combisystems in conjunction with auxiliary heating using electricity, biomass, or other fuels. A solar combisystem utilises an active solar thermal collector for space heating and to heat domestic hot water (DHW). Approximately one quarter of the 1,000,000 $\mathrm{m}^{2}$ of solar collectors installed in central Europe in 2001 were used as combisystems [9]. In Sweden the share of collector area installed as of 2001 was significantly larger for combisystems than the collector area installed for DHW alone, and it is assumed that in the next ten years that a minimum of $20 \%$ of collector area installed annually at middle to northern latitudes will be used for solar combisystems [8].

Intrinsic complexity of systems in conjunction with various incentive programs, and fuel costs of different countries has led to widely differing system designs. However, the basic principle of promoting stratification of water in the storage tank is found in all designs. What varies is the size and type of collector, the size of thermal storage, the type of auxiliary heating, and the control strategy. Years ago, combisystems had various main components: collector array, space heating storage tank, DHW storage tank, electronic control and a boiler. The use of a large number of components resulted in problems with the hydronic system and the controller, and the complex design reduced efficiency. The new approach is to have a single stratified storage tank that serves as an 
energy manager. Each energy source (solar and auxiliary), and different draws from the tank are connected to different heights to maintain the temperature layers in the tank, which avoids mixing and maintains stratification. These changes led to lowering the required number of pipes from 17 to 8 , and reduced the space requirements from $4.8 \mathrm{~m}^{2}$ to $2.2 \mathrm{~m}^{2}$, and lowered the system weight from 250 to $160 \mathrm{~kg}[10]$.

Certain systems utilise large seasonal thermal storage to help increase the fraction of solar energy used throughout the year. Using current technologies and costs, solar heating systems with short-term heat storage that are combined with high standards of thermal insulation of the building is a more costeffective system with higher efficiency than using seasonal storage [8]. It is possible that future heat storage technologies will be cheaper and more compact to make it a viable option to have seasonal storage.

Current systems in Europe vary in size such that the solar contribution of the heating systems ranges from 10 to $100 \%$. In the Netherlands, small systems comprising of 4 to $6 \mathrm{~m}^{2}$ collector, and $0.3 \mathrm{~m}^{3}$ storage tank are more typical, whereas in Switzerland, Austria, and Sweden larger systems using 15 to $30 \mathrm{~m}^{2}$ of collector area and 1 to $3 \mathrm{~m}^{3}$ thermal storage are typical. The larger systems allow for 20 to $60 \%$ of the heating demand to be met by solar, and for extremely well insulated house, and low-flow mechanical ventilation, solar contribution can reach $100 \%$ [8]. In general, the expected range of collector area is 4 to $8 \mathrm{~m}^{2}$ for DHW systems and 10 to $30 \mathrm{~m}^{2}$ for combisystems.

One problem with sizing the collectors to meet both the heating and DHW load in the winter is that in the summer, the collectors will generate too much heat. The heat needs to be discarded in order to avoid overheating in the collector, which can cause damage to the collector, and could break down the working fluid (glycol). One option is to use façade integrated solar collectors. Façade integration is beneficial as the collector receives a more evenly distributed amount of solar radiation over the year. Summer peak generation is reduced compared to roof systems but it will still be sufficient to heat DHW, and will reduce the potential of overheating. An added benefit of utilising façade integration is that it results in a higher effective Uvalue for the wall during cold days. Simulations have shown that the effective U-value of a wall with a façade collector is reduced by up to $90 \%$ during cold winter days with high irradiation, and by up to $45 \%$ during days with low irradiation, because the temperature of the outer layer of the wall - the collector - is higher than the ambient temperature outside. Monitoring of test façades confirmed the simulations [10].

\section{Auxiliary heating systems}

Even if the ZESH utilises solar energy for both space heating and DHW, there will most likely be a requirement for an auxiliary heating source for extended periods of cold weather, and for extended overcast conditions with limited insolation. There are many interesting energy efficient sources of heat that could be used such as ground source heat pumps. What needs to be considered is the total heat load that the auxiliary heater will need to provide. If the house can meet $90 \%$ of its heating requirements with solar, it may not make sense to install a $\$ 10,000$ heating system to provide only $\$ 100-\$ 200$ worth of heating a year [5]. On the other hand, if the net-zero energy target is to be met, and that electricity is used for back-up heating, then the cost of using an inefficient heating system will result in having to purchase more PV to generate electricity, which would most likely cost more than using the efficient heating system at the current cost of PV. The issue of selecting the most cost effective heating system for a ZESH is a complicated issue that is currently being investigated by the authors of this paper. Solutions will differ with local climatic conditions, control strategies and electricity pricing schemes that may vary with time of day.

Domestic hot water

Tankless heaters provide users with endless hot water at high appliance energy efficiency performance compared to storage devices, however, they draw large amounts of power in an unpredictable manner [11]. This would not be too bad for natural gas systems, however, if electricity is used this could drive up peak loads and create problems for utilities. There is a way to mimic tankless heaters by using smart tanks that are heated from the top down providing the ability to control the heated volume, and to have faster recovery of usable water. Dennis (2003) suggests using smart tanks with predictive control to only heat the amount of water that would be required by users at a given time. For example, little hot water is consumed at night, whereas, large draws can be expected in the mornings when various occupants have showers. In the case of the ZESH, which will depend on solar thermal energy to heat the DHW, a modified approach could be taken that utilises these principles.

The smart tank principle can be used to increase the solar fraction utilised by a solar DHW system. Furbo S., et al. (2003) did an analysis that demonstrated the yearly thermal performance of systems with smart 
solar tanks to be $5-35 \%$ higher than the thermal performance of traditional solar DHW systems, depending on hot-water consumption, and consumption patterns. As with a traditional system, the smart solar tank can be heated by solar collectors and by an auxiliary energy supply. The tank is designed such that the auxiliary heat to the tank comes from the top. As with a stand alone smart tank, the energy supply from the electric heating element is controlled in such a way that during all hours the energy content in the top of the tank has a predetermined variable minimum quantity fitted to the hot-water demand, allowing the water volume heated by the auxiliary system to be varied as wanted and reduced to a minimum. The solar collector fluid heats up the DHW by means of the mantel. A side-arm loop draws water from the middle to the bottom of the tank and circulates it back to the top of the tank after it has been heated. A diagram of the smart solar tank investigated in [12] is shown in Figure 2. The circulation can either be caused by thermosyphoning or by a pump.

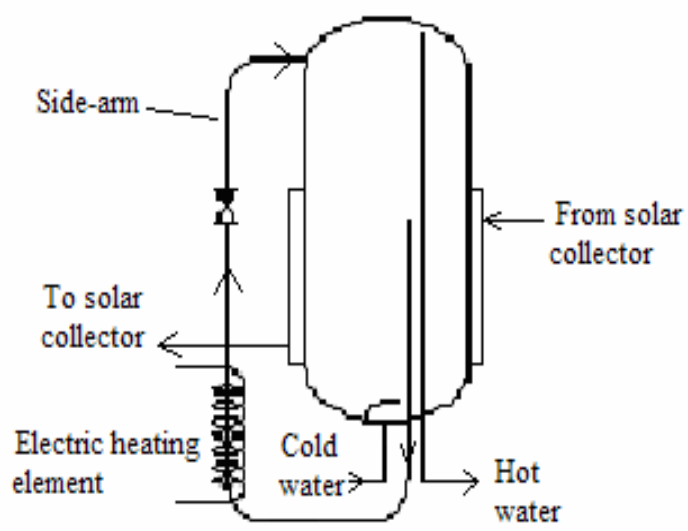

Figure 2: Smart Solar DHW Tank [12]

Different configurations of the auxiliary heating system can exist. In [12], the side-arm tank, and a tank that utilized both a horizontal and vertical electric heating element at the top of the tank were considered. The investigation revealed that the thermal performance of a system with smart solar tank with side-arm was somewhat greater than the performance of a smart tank with two built in electric heating systems. Other configurations exist that may yield different results. The investigation also revealed that smart solar tanks are suitable for unknown, variable, large or small hot-water consumption patterns and that risk of oversized solar heating systems and oversized tank volumes is reduced.
Smart solar tanks are most attractive if most of hotwater consumption takes place in the evenings, and least attractive when consumption is evenly distributed throughout the day. Reduced consumption during the day allows for a greater volume of water available to store the solar energy. The volume of the smart solar tank can be smaller than the volume of a traditional solar tank, the height of mantel for transferring solar heat can be greater for smart solar tanks, and a simple control system for auxiliary energy supply system based on a few temperature sensors in the top of the tank is almost as good as an advanced control system keeping track of the energy content in the top of the tank. And even though the estimated cost of a small solar DHW with smart tank is estimated to be $10 \%$ higher than traditional solar DHW systems with electric auxiliary heating, the performance/cost ratio is about $25 \%$ by using the smart-tank. A smart solar tank may be suitable for the ZESH. However, if the solar DHW is combined with the heating system through the use of a combisystem or other configuration, modifications to the concept would need to be made.

\section{$\underline{\mathrm{PV} \text { and } \mathrm{PV} / \text { thermal solar energy systems }}$}

In the past two decades, research and development have improved the efficiency and reliability of photovoltaics, and reduced the cost of photovoltaic electricity. Because of their overall efficiencies and material stability, the crystalline silicon-based technologies (single, poly and ribbon) currently occupy over $80 \%$ of the market. The historic learning curve for PV modules shows a $20 \%$ price reduction for every doubling of the accumulated sales. The invariance of the experience curve for PV modules over this period corresponds to more than thirteen doublings of cumulative production. This experience, in conjunction with the expected technological improvements from the R\&D labs leading to higher module efficiencies in the range of 15 to $18 \%$ by 2010 , and the automation of production lines resulting in module price declines to $2.00 \mathrm{US} \$ / \mathrm{W}_{\mathrm{p}}$ by 2010 , form reasonable bases for expectation that, with continued investments, a similar progress ratio is likely past 2010. The building of larger crystalline silicon manufacturing plants and the development of "thinner" silicon technologies that use less material will be important factors in reaching future industry cost targets. It has been predicted that the cost of PV electricity decreases to 0.08 US $\$$ per $\mathrm{kWh}$ by 2020 without heat recovery. Assuming that twice as much heat is also recovered, the cost could drop to about $0.04 \mathrm{US} \$$ per $\mathrm{kWh}$.

In addition, amorphous silicon solar cells with peak conversion efficiencies between 5 and 13\% have gone 
into continuous production (UNI-SOLAR). A number of manufacturers are encapsulating PV cells between glass sheets or even depositing amorphous PV onto glass substrates. Modules are now being used in building "curtain-wall" assemblies, as energy producing building cladding, as semi-transparent glazing, or incorporated into shingles for roof coverings [13].

Thermal solar energy systems can convert solar energy into heat at a rate greater than $80 \%$. The integration of PV and solar thermal technologies could result in a combined $\mathrm{PV} / \mathrm{T}$ system that could convert up to $80 \%$ of the available solar energy and benefit from the shared packaging, mounting and installation costs. It is expected that the equivalent energy costs for the combined system would be under $\$ 2.50$ per peak Watt (electrical/thermal) and could approach $\$ 1.50$ per peak Watt in the future. When compared to conventional PV generated energy at $\$ 8$ per peak Watt, the combined system significantly improves the cost effectiveness of delivering high-grade solar energy. Although both PV and solar thermal technologies are relatively well developed, their integration into a single combined unit presents a number of technical challenges. In particular, silicon based PV cells operate most effectively at cooler temperatures; however, conventional solar-thermal collection relies on achieving relatively high temperatures in the solar collector. Certain new PV technologies are less sensitive to increased temperatures but tend to be expensive.

A number of key issues involved in the integration of these two technologies relate to the solar receiver itself. Photovoltaics are electrical devices and therefore must be electrically insulated from each other and their substrate. Solar energy absorbed in the surface of the solar cells will be converted into electricity and heat. A requirement for the integrated solar receiver is that it effectively removes heat from the absorbing (PV) surface. This will require the design of an efficient heat removal mechanism in the solar receiver. PV cells are also fragile and subject to breakage during handling and if subjected to thermal shocks or extreme temperatures. The combined $\mathrm{PV} / \mathrm{T}$ receiver must maintain its performance over the life of the system while being exposed to extreme temperature, moisture and UV extremes. There have been a few notable attempts to merge PV and solar thermal technology with two recent efforts worth noting. The first is related to the development of a combined PV/T solar collector. Based on the "MaReCo", [14] non-tracking, low-concentrating thermal collector, it is best suited for high latitude locations where integration into the building façade is possible. An absorber is positioned in an east-west orientation and a compound parabolic concentrator is used to direct sunlight on its surface. Concentration ratios are typically low, (i.e., 3x) but will result in higher PV temperatures, (an undesirable situation), if not actively cooled. To remedy this situation, excess heat is transferred to a fluid circulating in channels below the cells. The authors claim that heat at $50^{\circ} \mathrm{C}$ can be produced from this system, and that about $300 \mathrm{kWh} / \mathrm{m}^{2}$ of heat, and $100 \mathrm{kWh} / \mathrm{m}^{2}$ of electricity, will be produced annually in Sweden, compared to a conventional (selective surface) thermal system that delivers approximately $400 \mathrm{kWh} / \mathrm{m}^{2}$ of heat annually [15]. The authors note that the major benefit of the system is the relative reduction in PV area required when using the reflectors and the benefit of providing both electricity and heat energy such as is done in co-generation applications. This concept, while having considerable merit, is hindered by its high temperature limitation imposed by the PV cell's temperature dependence.

Another concept that has been commercialized by Conserval Engineering Inc. of Toronto is referred to as "SolarRoof" [16]. This product utilizes their SolarWall perforated-plate, air-preheater as an underlay for conventional PV modules. "Solarwall ${ }^{\mathrm{TM} \text { ", }}$ is a cost-effective system applied to opaque walls in commercial and residential buildings to preheat fresh air; its perforated absorber plate also serves as inexpensive cladding material that can be architecturally integrated in façades. In the SolarRoof, air is drawn through gaps around and behind individual PV modules.

\subsection{Case study}

Concordia University and the University of Montreal are collaborating to represent the only Canadian participation in the 2005 Solar Decathlon competition that will take place in Washington DC. They will be using advanced building systems and equipment such as motorized shading, digital dimming and lighting control. Using unique thermal collection and storage techniques, the house temperature can be controlled with as little use of electricity powered HVAC as possible. With the use of in-house developed design and simulation tools using MathCAD, detailed models of the house were developed in order to have the most complete and accurate picture of its behaviour as a system. The house will be powered by approximately $60 \mathrm{~m}^{2}$ of photovoltaic modules on the roof and the façade. One of the innovative features of the house will be the use of the heat captured from the PV modules to heat fresh air that is either 1) passed through thermal 
storage in the floor or 2) used as the fresh air supply to the heat pump or 3) to preheat domestic hot water through the use of an air-to-water heat exchanger. The floor will also be used to cool the house in the summer by passing in the cool night air. A solar collector will be installed on the roof to aid in the hot water heating. The roof will have a tilt of approximately 30 degrees to balance the need for maximizing incident solar radiation with adequate interior ceiling height for daylighting. Figures 3 and 4 show a brief overview of the systems that will be present in the house as well as the DHW system.

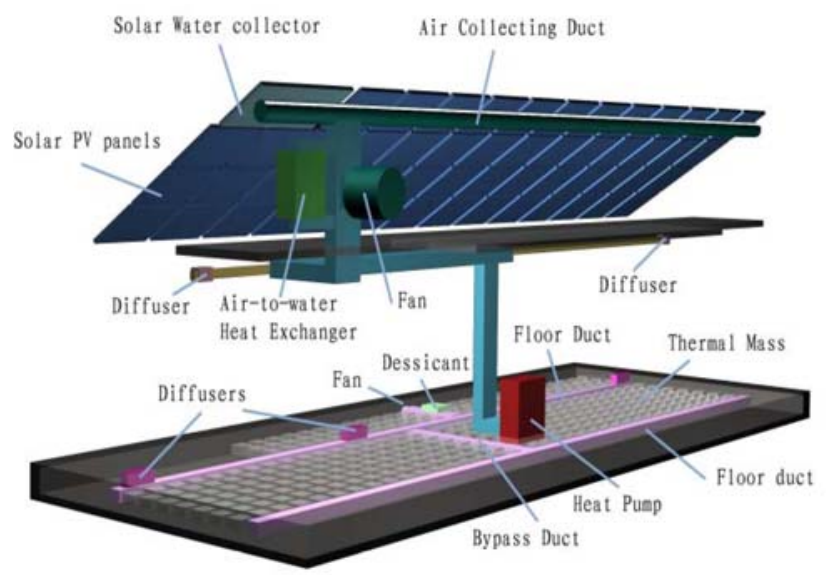

Figure 3: System view of PV, Solar Thermal, HVAC and thermal storage components

Simulations show that with the use of passive solar energy design principles, the house is able to achieve desired performance such as a low heating load on a typical cold, clear winter day and a small cooling load on a typical hot clear sunny day. MathCAD was used to implement thermal network models of windows (clarity, glazings, emissivity), thermal storage, infiltration, and to study various control strategies. Most modeling was done through the calculation of equivalent resistance or conductance (and capacitance if applicable as in thermal storage) and solving as an electrical network analogue (RC circuit). Heat flow is analogous to current, temperature is analogous to voltage, thermal storage is analogous to capacitance, and thermal resistance is analogous to a resistor or a capacitor. The only difference is that heat flow has units of power, whereas current does not. The MathCAD program integrates electrical, thermal, and daylight to give a more complete picture of the overall energy use. Modeling of heat gains, shading (interior, exterior, in cavity), lighting aspects of solar radiation, and net efficiency of PV taking into account temperature effects are all achieved.

The design day for summer represents a clear, sunny day in Washington D.C. in October with sinusoidal outdoor temperature varying between $15^{\circ} \mathrm{C}$ and $25^{\circ} \mathrm{C}$. The simulation also includes the heat gains due to the visitors, assumed to be $2 \mathrm{~kW}$ over 3 hours. The average daily cooling load was estimated at $12 \mathrm{kWh}$ without the use of thermal storage. When including the thermal storage capabilities of the floor, the cooling load was reduced to $4.5 \mathrm{kWh}$. The use of the thermal storage must be strategically planned. In this case, the night air (if it is at a temperature below $\sim 18^{\circ} \mathrm{C}$ ) is passed through the floor at $0.5 \mathrm{~m} / \mathrm{s}$ between the hours of $10 \mathrm{pm}$ and $8 \mathrm{am}$. The room air is then circulated through the floor between $2 \mathrm{pm}$ and $5 \mathrm{pm}$ to provide free cooling. This demonstrates that with the use of an intelligent control algorithm that a significant reduction of cooling energy requirements can be achieved.

The winter design day represents a clear, cold day in Montreal, Canada, with a sinusoidal outside temperature between $-15^{\circ} \mathrm{C}$ at night to $-5^{\circ} \mathrm{C}$ during the day. By allowing the temperature within the house to go as low as $18^{\circ} \mathrm{C}$ at night, it still requires significant electrical heating without the use of thermal storage, and the heat pump fluctuates on and off, as can be seen in Figure 5. The daily heating load was calculated as $9 \mathrm{kWh}$. Figure 6 shows the contribution of the Trombe wall and the thermal storage in the floor in reducing the heating load. As can be seen, the heat pump comes on much less often, leading to a daily heating load of $3 \mathrm{kWh}$.

Simulations were also performed for the entire year to see what the thermal load would be in the house while trying to maintain a relatively comfortable temperature throughout the year. Table 1 summarizes the results using data for average days. It should be noted that the temperature variation within the house is less with the use of thermal storage in addition to having smaller thermal load - two major benefits of thermal storage. The Canadian team aims to show the public that when designing a house with optimization of solar energy in mind, exceptional results can be achieved by combining simple passive solar techniques with innovative control techniques and a PV/thermal system. 


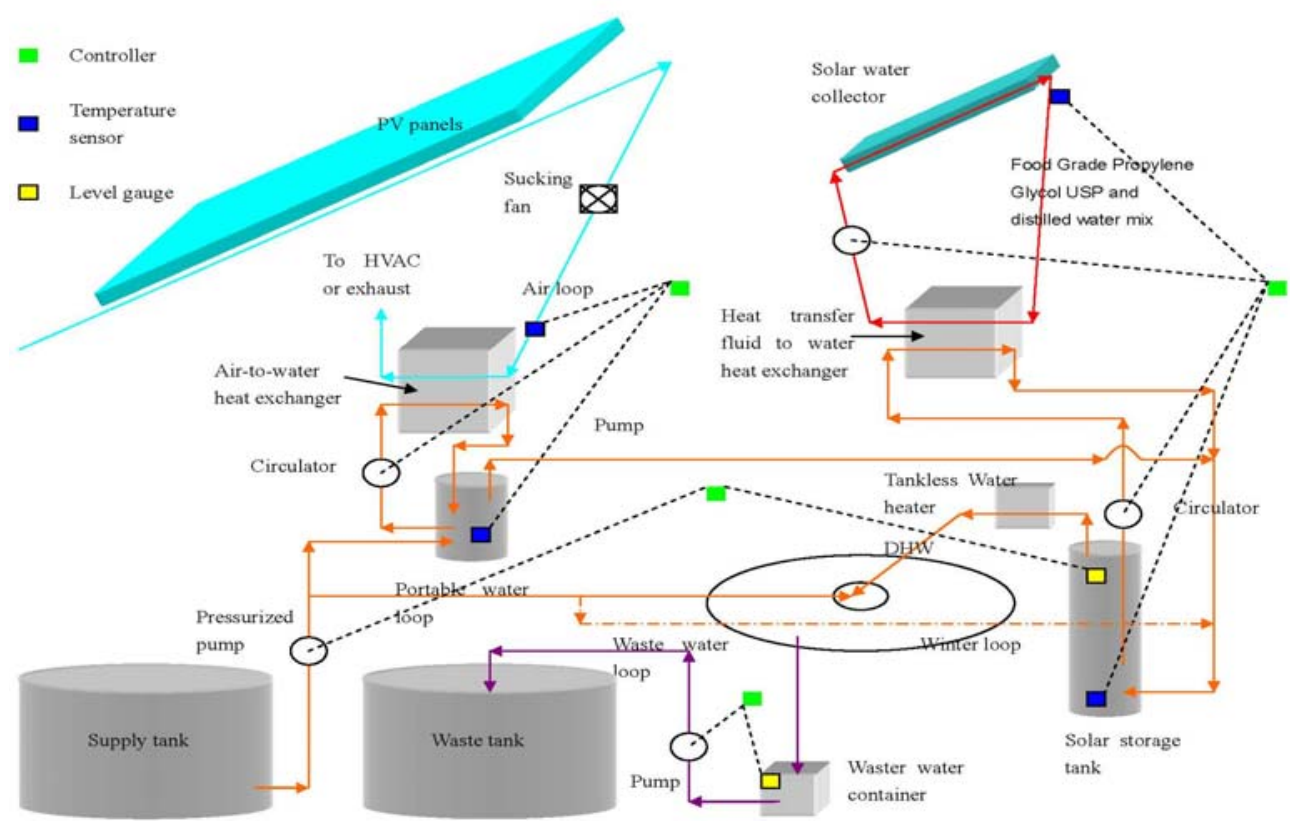

Figure 4: System view of DWH components

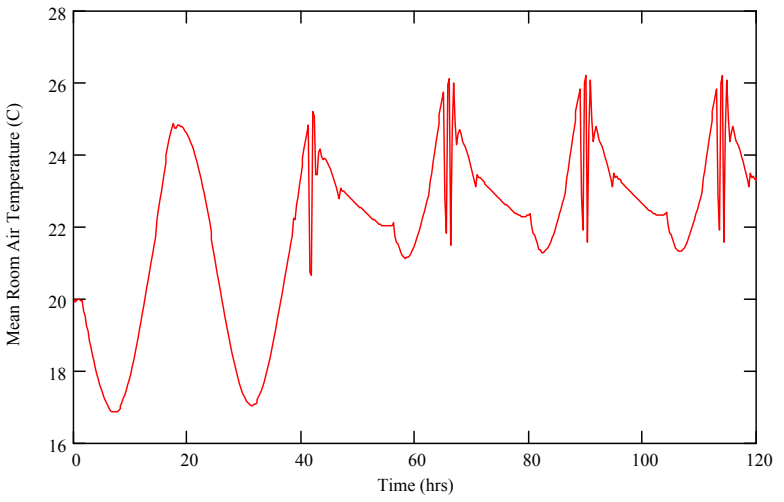

Figure 5: Temperature variation within house without the use of thermal storage

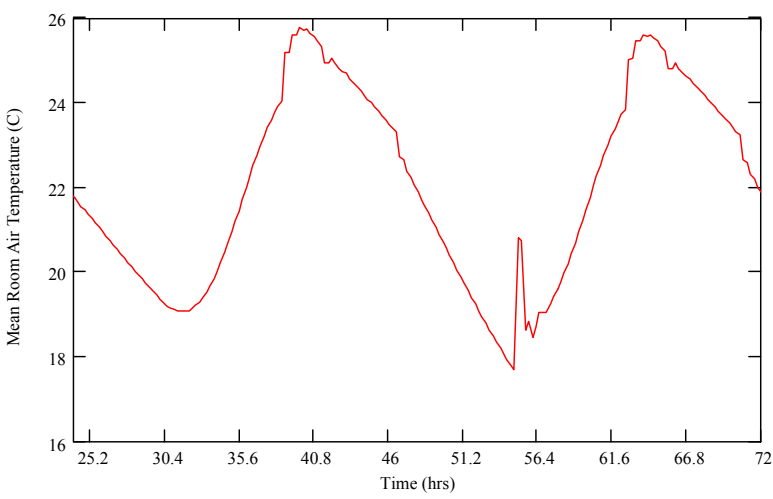

Figure 6: Temperature variation within house with use of thermal storage

\subsection{Discussion}

As we have seen, designing a ZESH involves the coupling of many different systems to achieve an energy efficient design, which also generates on-site energy using renewable energy technologies to satisfy its yearly energy needs. The design involves the use of various types of systems, which can vary depending on the specific design objectives, the project location, the knowledge of the designer, etc., all of which leads to many different configurations of ZESH. This can be observed by examining the various net-zero and low energy building demonstration projects from around the world [4]. The projects depended on trial-and-error optimization using dynamic energy simulation tools, coupled with the knowledge of the designers. Simulations are normally used in a scenario-byscenario basis, with the designer generating a solution and subsequently having the computer evaluating it. This can be a slow and tedious process and typically only a few scenarios are evaluated from a large range of possible choices [17].

Although a reduction in the energy use of residential buildings can be achieved by relatively simple individual measures, very high levels of performance require the coherent application of measures, which together optimize the performance of the complete building system. This multi-component optimization problem can lead designers to feel ill-equipped to tackle such a task. The application of computerized 
Table 1: Summary of modeling results for average days in Washington D.C.

\begin{tabular}{|c|c|c|c|c|c|c|c|c|c|c|c|c|}
\hline $\mathrm{T}\left({ }^{\circ} \mathrm{C}\right)$ & Jan & Feb & Mar & Apr & May & Jun & Jul & Aug & Sep & Oct & Nov & Dec \\
\hline $\begin{array}{l}\text { Max (w/o thermal } \\
\text { storage) }\end{array}$ & 25 & 26 & 29 & 29 & 26 & 25 & 25 & 25 & 25 & 25 & 26 & 26 \\
\hline $\begin{array}{l}\text { Min (w/o thermal } \\
\text { storage) }\end{array}$ & 19 & 18 & 21 & 23 & 24 & 23 & 23 & 23 & 22 & 22 & 20 & 19 \\
\hline $\begin{array}{l}\text { Thermal Load - } \\
\text { kWh (w/o thermal } \\
\text { storage) }\end{array}$ & 6 & 0 & 0 & 0 & 7.5 & 15 & 18 & 18 & 15 & 6 & 0 & 0 \\
\hline $\begin{array}{l}\text { Max (with } \\
\text { thermal storage) }\end{array}$ & 23 & 25 & 26 & 24.5 & 26 & 25 & 25 & 25 & 25 & 24 & 24 & 24 \\
\hline $\begin{array}{l}\text { Min (with thermal } \\
\text { storage) }\end{array}$ & 19 & 19 & 22 & 20.5 & 22 & 23 & 23 & 23 & 20 & 20 & 21 & 20 \\
\hline $\begin{array}{l}\text { Thermal Load - } \\
\text { kWh (with } \\
\text { thermal storage) }\end{array}$ & 3 & 0 & 0 & 0 & 0 & 9 & 12 & 9 & 1.5 & 0 & 0 & 0 \\
\hline Shading Strategy & None & None & $\begin{array}{l}70 \%: \\
12-14 \mathrm{~h}\end{array}$ & $\begin{array}{l}70 \%: \\
10-15 \mathrm{~h}\end{array}$ & $\begin{array}{l}70 \%: \\
9-17 \mathrm{~h}\end{array}$ & $\begin{array}{l}70 \%: \\
9-17 \mathrm{~h}\end{array}$ & $\begin{array}{l}70 \%: \\
9-17 \mathrm{~h}\end{array}$ & $\begin{array}{l}70 \%: \\
9-17 \mathrm{~h}\end{array}$ & $\begin{array}{l}70 \%: \\
9-17 \mathrm{~h}\end{array}$ & $\begin{array}{l}70 \%: \\
9-17 \mathrm{~h}\end{array}$ & $\begin{array}{l}70 \%: \\
9-17 \mathrm{~h}\end{array}$ & $\begin{array}{l}70 \%: \\
11-15 \mathrm{~h}\end{array}$ \\
\hline
\end{tabular}

optimization techniques to the design of low and zero energy buildings would provide architects and engineers with a powerful design tool [18]. Another drawback of the traditional trial-and-error method is optimum designs are site specific; even if an excellent, most optimum design, is created by a group of expert designers, its functionality would be different in different climates. A design using an air-to-air heat pump might work well in Victoria but would most likely fail in the cold Edmonton climate.

The use of optimization rather than simulation is thus proposed to find the optimum design of a ZESH. In recent years, Genetic Algorithms (GA) have been used to optimize different building systems including optimizing solar collector and storage tank size [19], a low energy community hall including shape of perimeter, roof pitch, constructional details of envelope, window types, locations and shading, and building orientation [18], window size and orientation with a solution space of $16,777,216$ points [17], conceptual designs of office buildings [20], HVAC sizing, control, and room thermal mass [21]. The use of GA in optimizing buildings and other engineering problems is emerging as this global search technique is adequate for searching noisy solution spaces with many local and global minima, and has proved to have high efficacy in solving complex problems for which conventional hill-climbing derivative-based algorithms are likely to be trapped in local solutions [17].

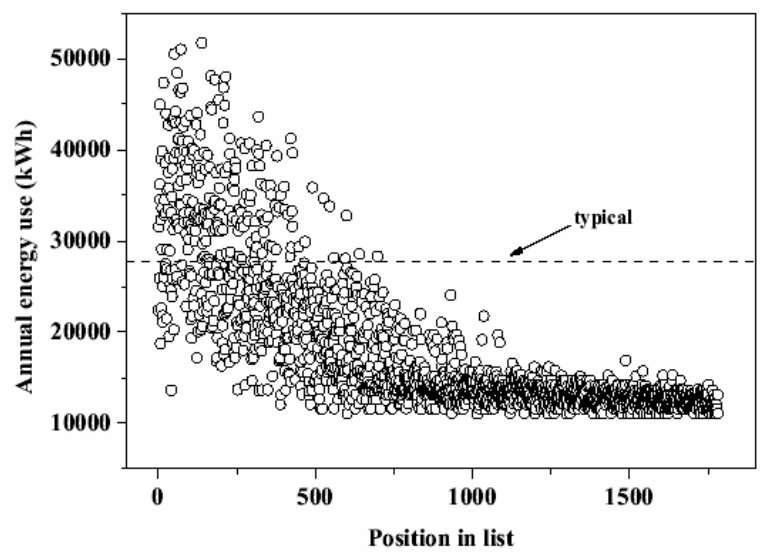

Figure 7: GA results for the designing of a community hall [18].

Another advantage of using GA is that it provides a population of optimum designs. Figure 7 shows the results of the use of GA in optimizing the construction of a low energy community hall in the UK [17]. As can be seen, there are countless possible design solutions that would use less energy compared to the average energy intensity for similar buildings in the UK $\left(137 \mathrm{kWh} / \mathrm{m}^{2}\right)$. What is even more useful is that the optimum designs can be very different, giving a lot of choice to the designer and/or building owner. For example, two of the more optimal designs that evolved in this study had very similar energy use, but were very different. One used high levels of insulation to reduce losses with minimal window area, while the other focused more on maximizing passive solar utilisation by having more windows and more thermal mass. 


\subsection{Conclusion}

The growing concern regarding global warming, the continual development of energy efficient appliances and HVAC systems, the expected drop in PV and solar thermal collector prices, and other driving factors should lead to the eventual mainstreaming of solar homes that either consume zero net energy, or in fact generate a surplus of energy. Design guidelines and technologies exist currently to generate ZESH. The limited design experience, the higher costs, and other factors are limiting their growth. The Solar Decathlon competition is an important tool in helping advance their application. The competition spurs innovation, while educating a large number of future building design professionals, including engineers, technicians, and architects. The design of this year's Canadian entry in the competition demonstrates that when designing a house with optimization of solar energy in mind, exceptional results can be achieved by combining simple passive solar techniques with innovative control strategies. Their efficient use of thermal mass both helped reduce heating and cooling loads and also to maintain a more comfortable environment. In order to help accelerate the uptake of ZESH, new design tools need to emerge that will help the designers determine the most cost effective mix of technologies that needs to be introduced to achieve the net-zero target such as a GA based optimization tool.

\subsection{Acknowledgments}

Financial support for this collaborative research project was provided in part by Natural Resources Canada through the Technology and Innovation Program as part of the climate change plan for Canada.

\subsection{References}

[1] www.solarhouse.com, viewed May 12, 2005

[2] Hamada Y., et al., 2003. Development of a database of low energy homes around the world and analyses of their trends, Renewable Energy 28, 321-328.

[3] Hoiting H., Donze G., Verhoef L. (2003) 10 Different Zero Energy Projects In The Netherlands. ISES Solar World Congress, Gothenburg, Sweden, 2 pp.

[4] Charron R., Athienitis A., 2005. An International Review of Low and Zero Energy Homes, ISES Solar World Congress 2005, Orlando FLA.

[5] Chiras D., 2002. The Solar House: Passive Heating and Cooling. Chelsea Green Publishing.Vermont, 274 pp.
[6] CMHC. 1998. Tap the Sun: Passive Solar Techniques and Home Designs. CMHC, Canada, 117 pp.

[7] Athienitis, A.K. and M. Santamouris, 2002, Thermal Analysis and Design of Passive Solar Buildings, James and James, London, UK

[8] Weiss W., Suter J-M., Letz T., 2003. Comparison Of System Designs Of Solar Combisystems. ISES Solar World Congress 2003, Gothenburg, Sweden, 5pp.

[9] Frei U., 2003. Solar Thermal Collectors, State Of The Art And Further Development. ISES Solar World Congress 2003, Gothenburg, Sweden, 8 pp.

[10] Weiss W., 2003. Solar Heating Systems - Status And Recent Developments. ISES Solar World Congress 2003, Gothenburg, Sweden, $11 \mathrm{pp}$.

[11] Dennis M., 2003. Optimising Energy Balance For Systems With Storage. ISES Solar World Congress 2003, Gothenburg, Sweden, 8 pp.

[12] Furbo S., et al., 2003. Smart Solar Tanks For Small Solar Domestic Hot Water Systems. ISES Solar World Congress 2003, Gothenburg, Sweden, 8 pp.

[13] Ayoub J., et al., 2001. Photovoltaic for Buildings: Opportunities for Canada, Natural Resources Canada

[14] Karlsson B., Wilson G., 1999. MaReCo - A Large Assymetric CPC for High Latitudes. ISES Solar World Congress 1999

[15] Brogren M., Karlsson B., 2002. Low-Concentrating Water-Cooled PV-Thermal Hybrid Systems for High Latitudes", Photovoltaic Specialists Conference, Conference Record of the Twenty-Ninth IEEE, May 19-24, 1733-1736.

[16] www.solarwall.com/roof/roofHow.html, March 2, 2005

[17] Caldas L., Norford L., 2002. A design optimization tool based on a genetic algorithm. Automation in Construction 11, 173-184.

[18] Coley D., Schukat S., 2002. Low-energy design: combining computer-based optimisation and human judgement. Building and Environment 37, 1241-1247.

[19] Kalogirou S., 2004. Optimization of solar systems using artificial neural-networks and genetic algorithms. Applied Energy 77, 383-405.

[20] Grierson D.E., Khajehpour S., 2002. Method for Conceptual Design Applied to Office Buildings. Journal of Computing in Civil Engineering 16, 83-103.

[21] Wright J., Loosemore H., Farmani R., 2002. Optimization of building thermal design and control by mutli-criterion genetic algorithm. Energy and Buildings 34, 959-972. 